\title{
The effects of road user charges in the context of weak parking policies: The case of Malta
}

\author{
Maria Attard ${ }^{\mathrm{a}, *}$, Stephen Ison ${ }^{\mathrm{b}}$ \\ ${ }^{a}$ Geography Department, Faculty of Arts, University of Malta, Msida MSD 2080, Malta \\ ${ }^{\mathrm{b}}$ Transport Studies Group, School of Civil and Building Engineering, Loughborough University, Loughborough, Leicestershire LE11 $3 T U$, UK
}

\section{A R T I C L E I N F O}

\section{Article history:}

Available online 11 July 2014

\section{Keywords:}

Road pricing

Parking

Malta

\begin{abstract}
A B S T R A C T
Road user charging is often thought of as a first best travel demand management solution for dealing with the issue of congestion, when compared to the use of parking charges. The case for this is that parking charges are more likely to result in improvements in the situation rather than an optimal outcome. One of the reasons is that parking can be seen as a complement to vehicle travel impacting on the termination point of a journey as opposed to charging directly for the use of road space as in the case of road user charging. In saying this parking charges are used extensively as a demand management measure and there are still only a few road user charging schemes worldwide. One scheme that has moved from a parking charge to a road user charge is the Controlled Vehicular Access system in Valletta, Malta where a fixed annual charge (V-licence) for access and parking into the city was replaced by a time-based road user charge implemented in May 2007. The aim of this paper is to assess the effects of road user charging in the context of ineffective parking policies, using the case of Valletta. The paper is based on scheme documentation, semi-structured interviews with key stakeholders, supplemented by personal observations of one of the authors directly involved in the process of developing and implementing the road user charging system. The research concludes that the overall impacts of the road user charge in the City were positive but more effort will have to be made to strengthen the road charging scheme and parking policy to effectively manage the travel demands of the islands' population.
\end{abstract}

(C) 2014 World Conference on Transport Research Society. Published by Elsevier Ltd. All rights reserved.

\section{Introduction}

Road user charging is often thought of as a first best travel demand management solution for dealing with issues of traffic and congestion, when compared to the use of parking charges. For many years the prevailing view has been that appropriate pricing is the best way to optimally utilize the road transport infrastructure (Ministry for Transport, 1964; Newbery, 1990). Despite this, parking charges are extensively implemented across cities worldwide as a demand management tool whilst road user charging is less common. Whilst road pricing schemes such as Singapore's Electronic Road Pricing (1998), London's Congestion Charge (2003), Stockholm's congestion charging scheme (2006) and Milan's (2008) Area C, have been implemented, others have failed to materialize with examples such as those of Cambridge and Edinburgh in the UK and New York in the US. One scheme that has

\footnotetext{
* Corresponding author. Tel.: +356 23402147.

E-mail addresses: maria.attard@um.edu.mt (M. Attard), s.g.ison@lboro.ac.uk (S. Ison).
}

transformed from a parking charge to a road user charge is that within the city of Valletta in Malta where a fixed annual charge (called the V-licence) for access and parking into the city was replaced by the Controlled Vehicular Access system (CVA), a timebased road user charge implemented in May 2007. This scheme was implemented as part of a wider strategy aimed at improving accessibility within the capital city. Other complementary measures included the development of park and ride and an extension of pedestrianization in the city's retail area. This was all implemented without a rigorous parking policy to manage demand and access to the city.

The aim of this paper is to assess the effects of road user charging in the context of relatively weak transport demand management and non-restrictive parking policies, using the case of Valletta. The paper is a case study analysis based on scheme documentation, semi-structured interviews with key stakeholders in Valletta, supplemented by personal observations by one of the authors directly involved in the process of developing and implementing the charging scheme.

The paper is divided into six sections with the literature review (Section 2) discussing parking charges and road user charging as 
measures to manage transport demand. Section 3 presents an overview of the case study, the islands of Malta, and details the development of transport policy in the islands over time. Section 4 discusses the method adopted for this study and Section 5 presents the findings, whilst Section 6 concludes the paper.

\section{Literature review}

Transport demand management (TDM) has been widely used as a means of influencing individual travel behaviour. Meyer (1999) defines TDM as any action or set of actions aimed at influencing people's travel behaviour in such a way that alternative mobility options are presented and congestion is reduced. Parking management has traditionally been a mechanism used to affect the use of road space (Bonsall and Young, 2010), however developments in technology have facilitated the direct charging of drivers for their use of the road space both when in motion and parked (de Palma and Lindsey, 2011).

Brown et al. (2004) argue that although parking is often perceived as passive, its management and control can generate great impacts, particularly on trip generation and distribution, network assignment, convenience, safety, travel time as well as the viability of modes that compete with the private car. Litman (2006) suggests that parking management could increase utilization of land and transport infrastructure in urban areas, especially when supply levels and pricing structures are optimized to improve efficiency and increase accessibility.

Particular strategies aimed at reducing congestion and increasing parking turnover have been associated with the effective pricing of long and short stay parking, so much so that increasing the price of long stay parking generally leads to a reduction of peak hour traffic and associated problems (Albert and Mahalel, 2006). On the other hand increasing short term parking and reducing its price is seen to support local retail economies (Shoup, 2005; Young, 2008).

Parking policy however has been associated with a number of difficulties such as the increase in illegal parking following the introduction of parking controls. Controls may also encourage cruising. This 'cruising for parking' contributes to congestion, vehicle miles travelled and increased emissions (Shoup, 2006). An increase in parking charges may cause motorists to park for a shorter period of time and whilst this allows more vehicles to park in a space each day, it can also increase traffic. For the same reason however motorists may prefer that parking is not free. Parking charges can also lead to displacement, with cars parking in nearby residential areas. Despite all this, parking pricing and controls are a commonly used strategy in urban areas worldwide.

Road user charging on the other hand has had very specific applications. Despite being advocated by transport economists as an efficient measure to reduce congestion and tackle growing concerns over urban transport demand and the impact on air quality, there are very few systems in place around the world. According to Button and Vega (2008) the role of an economic price is to allocate the supply, indicate changes in capacity and provide financial resources (Button and Vega, 2008). Many still underestimate the importance of the first two roles.

The success of cities like Singapore, London, Stockholm and Milan in terms of implementing a road user charge has not been enough to persuade other city authorities to adopt road user charging as a means of managing congestion. This has mainly been the result of a lack of public support (Ison and Rye, 2005) however road user charging goes further than parking policy and offers support for broad land use and transport policy objectives. Charging motorists for their external costs improves network efficiency and releases funds for investment elsewhere. Ison (2004) states that in addition to raising revenue, urban road charging can make a contribution to reducing congestion, rationing road space and improving local environments, mitigating climate change in the process and enhancing social inclusion and equity. More recent attempts at road user charging have focused on increased liveability and sustainability of urban areas (PRoGR€SS, 2013).

Parking and road user charging both rely on the price mechanism to influence driver behaviour. Their purpose might be similar however with their impact very much dictated by location and design. Changing from one system to another certainly impacts the transport system, as well as travel behaviour and the economy.

\section{Overview of the case study}

Malta is one of the smallest states in Europe and has a population of just over 400,000 inhabiting an area of $316 \mathrm{~km}^{2}$ (National Statistics Office, 2011). This makes the islands one of the most densely populated areas in the world. Fig. 1 shows the islands administrative boundaries, its dense road network and the built up area which covers just over $27 \%$ of the territory (National Statistics Office, 2011).

Malta became independent from the British in 1965, but it was only in the 1990s that the islands experienced the first economic boom with increased standards of living, household income and car ownership. Fig. 2 shows the islands growth in car ownership compared to the 2010 motorization rates of other European countries. In 2010 Luxemburg registered a higher rate of motorization (659) followed by Iceland (649), Italy (606), Cyprus (575) and then Malta (573) (National Statistics Office, 2011). A 'predict and provide' policy in favour of private motorization led to the construction of an extensive road network (today extending to over $2000 \mathrm{~km}$ ), servicing predominantly the urban area. Over $90 \%$ of the inhabitants are considered urban and live within the agglomeration surrounding the Central Business District (CBD) which is also the capital city - Valletta.

Valletta and its suburb Floriana are surrounded by fortification walls and built on a peninsula, limiting dramatically the provision of infrastructure for vehicular access. Currently there are only three roads that lead into the city. The area is small, at just over a kilometre squared, but the density of activities is very high attracting a relatively large number of commuters and visitors daily.

The rate at which traffic has increased in Valletta over the years reflects increased car ownership rates in the islands. These were in parallel with the construction and development of the road network over time, with the number of cars per $\mathrm{km}$ of road remaining relatively stable during the 1990s and early 2000s despite the rapid increase in the number of vehicles (Attard, 2006).

\subsection{Policy overview and timeline}

Transport policy following independence has been very weak with traces of policy documented in party electoral programmes (Attard, 2006), until 2004 when the Cabinet of Ministers approved the first ever Sustainable Land Transport White Paper. This 10-year policy document was developed by, the then, new transport regulator. The main objectives of the White Paper focused on achieving a modal shift from private to public transport, ensuring safe travel for all users, encouraging healthier travel and increasing the accessibility of transport infrastructure. In particular, one of the objectives of the White Paper aimed for a $20 \%$ reduction in onstreet parking and the introduction of parking management tools in an attempt to restrain non-essential car use. Despite this, very little has been achieved in terms of the implementation of parking restraint. 


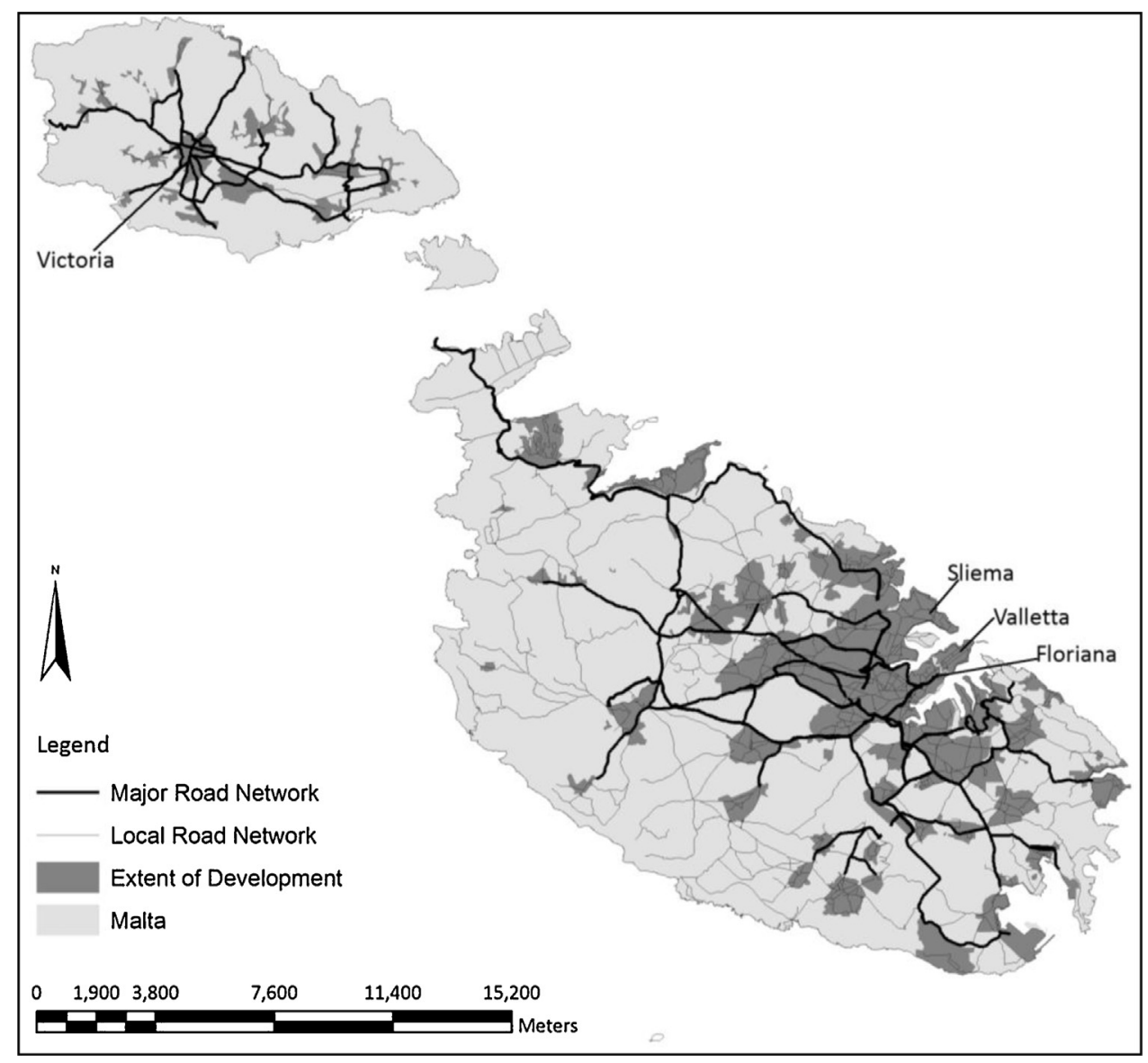

Fig. 1. The islands of Malta.

Source: Attard (2006).

One 'restrictive' scheme controlling the parking in Valletta was the $\mathrm{V}$-licence, a fee over and above the annual road tax paid by car owners to park in the city. Introduced in the 1960s it had become inefficient due to the relatively low fee ( $€ 46$ per year) and the high number of cars paying for parking in the city which, as will be described later, exceeded the parking capacity of the city by a great deal. Between 2006 and 2007 the Government went on to remove the annual V-licence and replace it with a road user charging scheme called the Controlled Vehicular Access (CVA) system, implement the first ever Park and Ride site on the outskirts of Valletta and extend pedestrianization in the city's commercial streets. All these projects were implemented as part of a strategy to improve accessibility to the capital city, the island's CBD. Of most interest to this paper is the road charging scheme (CVA) which saw Malta follow the likes of Durham (2002), London (2003), Stockholm (2006) and subsequently Milan (2008) in introducing road user charging. Table 1 summarizes the operation of the scheme in Valletta.

In all this, parking policy continued to feature very little. With the exception of Valletta, motorists in Malta still enjoyed free onstreet parking with a few private commercial parking facilities in primary town centres. An informal system of car park attendants developed over time whereby users tip an attendant on-site in public (government owned) off-street parking areas. These informal car park attendants were eventually "licensed" by the transport regulator and assigned a specific parking area in the early 2000 s in an attempt to curtail the on-site wars between individuals touting for tips. These however contributed very little to demand management, apart from raising questions as to whether the whole operation, run by private individuals without a title or contract, is either legal and fair. In popular parking areas it is evident that abuse still occurs with car park attendants parking vehicles illegally in an effort to cram as many cars as possible into one area and attend to those cars with owners leaving their keys inside. Those willing to take such risks pay more and are given priority. This way parking areas increase their capacity by an average of $30 \%$ (Cabinet Committee for National Projects, 2005). In addition car park attendants pay no rent for the land on which they operate, nor do they pay tax on the revenue raised. Drivers therefore pay an opportunity cost for using the land with most of it never reaching

Table 1

Principles of the Controlled Vehicular Access system.

\begin{tabular}{|c|c|}
\hline Regulator & $\begin{array}{l}\text { Malta Transport Authority, } \\
\text { subsequently Transport Malta }\end{array}$ \\
\hline Contractor & CVA Technology Ltd \\
\hline Entry/exit points & 11 sites \\
\hline Charging times & $\begin{array}{l}0800-1800 \text { weekdays; } 0800-1300 \text { Saturdays } \\
\text { free on Sundays and public holidays }\end{array}$ \\
\hline Charges & $\begin{array}{l}\text { Free first } 30 \mathrm{~min} \text {; } € 0.82 \text { per hour up to a } \\
\text { max of } € 6.52 \text { per day }\end{array}$ \\
\hline Pre-payment & $10 \%$ discount \\
\hline Full exemption & $\begin{array}{l}\text { Residents and their children; service vehicles } \\
\text { for works; police and emergency vehicles }\end{array}$ \\
\hline Technology & $\begin{array}{l}\text { Automatic Number Plate Recognition (ANPR) } \\
\text { for monitoring entrance and exit and calculating } \\
\text { time spent in zone }\end{array}$ \\
\hline Billing & Monthly bills sent to vehicle owner \\
\hline
\end{tabular}




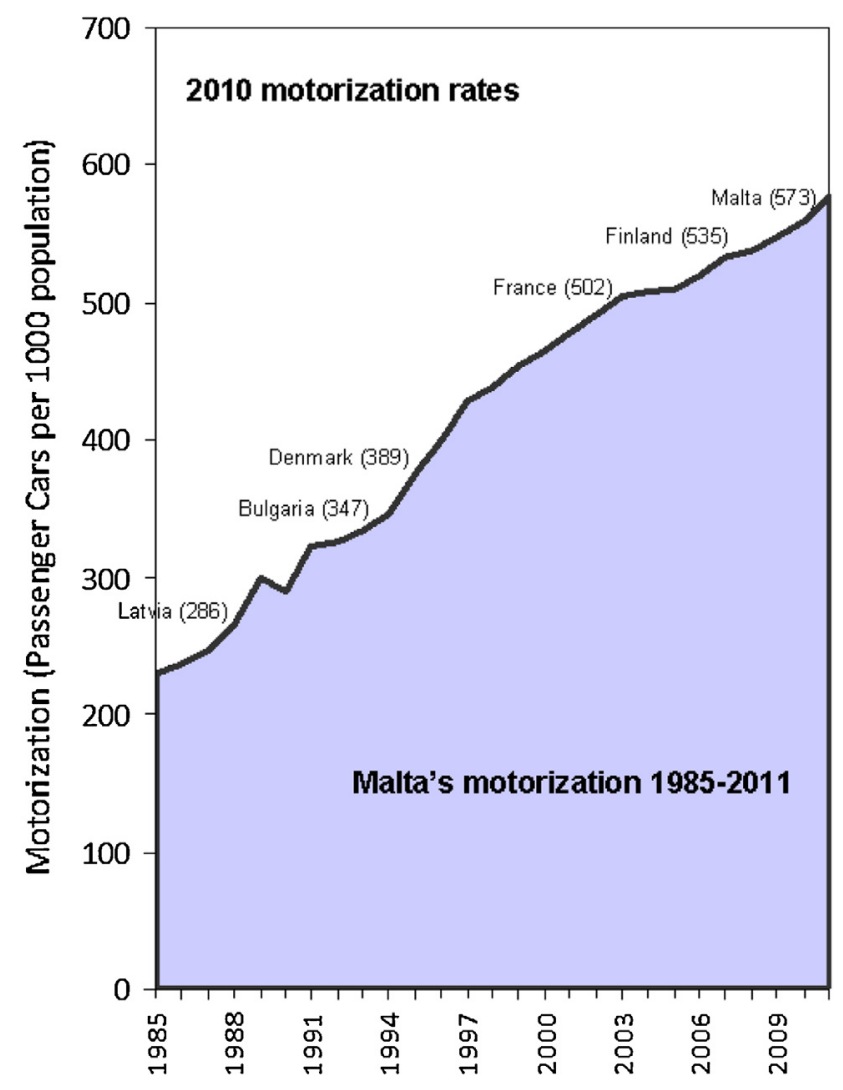

Fig. 2. The growth in car ownership (National Statistics Office, 2011; European Commission, 2012).

the actual land owner (Government). Indeed because the attendants are informal and not regulated, the cost of parking (the tip) does not reflect in any way the objectives of costing the value of the land and the external costs of parking to optimize the level of congestion on the roads and optimize the activity of parking itself (Verhoef et al., 1995). These car park attendants were removed in Valletta following the introduction of the CVA system, however the practice remains widespread in all other areas of the islands.

In 2004 a Government committee was set up to draft guidelines for controlled residents' parking schemes. These schemes were aimed at introducing time constraints on the use of parking spaces in areas where many different users, in particular residents, battled with a considerable number of visitors and commuters using and parking their cars within what could be considered residential areas (a loose term in the Maltese context given the morphology of most villages and cities in the islands having a complex land use of both commercial and residential land uses in close proximity). The scheme did not introduce charges but protected the residents' interests over visitors by limiting the amount of time spent parking in the same space. Residents were exempt and could park anywhere and without any time constraints. These schemes were implemented in a number of primary town centres (with the exception of Valletta due to its existing scheme) and, because the process involved the participation of all stakeholders including the local councils, retail, employer unions and central government, there was generally agreement as to the adoption of such schemes. No studies were ever carried out on the success and impact of these schemes but their high public acceptability possibly reflects positive outcomes. Despite this, the recent attempts by the Sliema Local Council to introduce a residents' parking scheme are proving difficult due to the conflicting (and in some cases unrealistic) demands made for a very limited parking capacity on-street. In this case the business community is requesting paid parking be introduced as an alternative (Times of Malta, 2013a).

On the 26th September 2012 Central Government issued a tender to privatize and regulate the parking operations in 34 public off-street parking areas, currently served by car park attendants (Transport Malta, 2012). The tender specified the requirements of the operation as well as guaranteeing a job for the incumbent car park attendant, should he/she not be in a position to match the offer made by other operators. The operators had to upgrade the areas, provide security, install access control measures, charge fees which were available to drivers prior to accessing the site and provide access $24 \mathrm{~h}$ a day, seven days a week (with the exception of areas in Rabat, Mosta and Floriana where car parks are used by residents for overnight parking, in which case charging is to be affected between 0800 and $1800 \mathrm{~h}$ only) (Transport Malta, 2012).

Despite the lack of documented government policy in the area of parking, this tender for the first time introduced the concept of paid parking in public car parking areas. Unfortunately this tender was heavily criticized by the public who saw this as a new tax, and by Local Councils who felt they should have been given the option to decide on the management of the public parking areas within their localities. Timing was also an issue since the tender was published a few months before a general election and the issue became highly political with the main objectives and benefits being 'lost in translation'. In the end the opposition was so great that Transport Malta, the Government's regulatory authority had to withdraw the tender and halt the process.

In the 2013 elections the three parties proposed different measures to counter parking and congestion problems. Table 2 shows abstracts of the three main parties' electoral programmes. The Nationalist Party persisted with their previous attempts to privatize and charge for parking. On the other hand the Labour Party proposed not only to maintain the current status quo of free parking but also to construct more parking infrastructure in areas

Table 2

Electoral programmes for the 2013 general elections (Partit Laburista, 2013; Alternattiva Demokratika, 2013; Nationalist Party, 2012)

\begin{tabular}{|c|c|c|}
\hline Nationalist party & Labour party & Alternattiva Demokratika (Green party) \\
\hline $\begin{array}{l}\text { In order to manage the traffic } \\
\text { situation better, we will } \\
\text { enter in to partnership with } \\
\text { the private sector to build car } \\
\text { parks in order to reduce the } \\
\text { current parking problem }\end{array}$ & $\begin{array}{l}\text { - Priority will be given to projects that address the problem } \\
\text { of parking, especially in commercial centres such as } \\
\text { Valletta, Sliema, Bugibba and Tarxien. We will endeavour to } \\
\text { construct a parking complex at the University of Malta } \\
\text { - Ensure that the existing public car parks will remain for } \\
\text { use by general public within any new fees. At the same time } \\
\text { improve the services provided and increase safety } \\
\text { - In order to stimulate commercial activity, the CVA system } \\
\text { will be reformed to make it easier and less prohibitive for } \\
\text { people to access the City. As part of this reform we consider } \\
\text { that access to Valletta is free after } 2 \text { pm and on Saturdays }\end{array}$ & $\begin{array}{l}\text { - Whilst in certain areas it is inevitable } \\
\text { that there will be parking for cars, the } \\
\text { first priority should always be the use of } \\
\text { public transport and the reduction of } \\
\text { cars from the road }\end{array}$ \\
\hline
\end{tabular}


already at capacity. In addition to the parking proposals the Labour Party also proposed reducing the Controlled Vehicular Access system charging times, allowing more cars to access the City for free (Partit Laburista, 2013). The Green Party had probably the most extensive list of measures to encourage and implement modal shift. There was however very little reference to parking with the exception of one statement in which they highlighted the need for parking in certain areas, even though this will not be done at the expense of promoting public transport and reducing traffic (Alternattiva Demokratika, 2013).

In March 2013, a Labour Government was elected and is showing a strong determination towards implementing the electoral promises made prior to the election. This does not augur well for the future of parking management or the Controlled Vehicular Access system in Valletta. There is already pressure on the Government to remove the residential parking schemes and the Government has already requested three Councils to suspend their plans for parking management (Times of Malta, 2013b). In the same article the Times of Malta (2013) reported that the Minister has requested the transport regulator to study possible parking schemes and develop a national parking policy.

\section{Method}

The research is primarily based on secondary sources and data collected prior to and after the removal of the V-licence and the introduction of the CVA scheme in Valletta. Government policy documents related to the implementation of the CVA are used and data from the system is analysed. The study is based on an in-depth understanding of the scheme development by one of the authors who played a major role in the process of designing and implementing the road user charge in Valletta. Direct involvement and personal observation therefore support this research. The author was involved in the team of experts appointed by a special Cabinet Committee of the Maltese Government dealing with National Projects and tasked with writing the policy, designing the scheme and subsequently implementing what would be later termed the Valletta projects. This position of 'insider' (Burgess, 1984) held by the author allowed for a natural interaction with individuals involved in the project.

\section{Findings}

This paper assesses the effects of road user charging within the context of in an ineffective parking policy which has been prevalent in the islands of Malta, using the cases of the V-licence prior to 2007 and the Controlled Vehicular Access system implemented in Valletta.

Valletta, is one of the first examples of town planning based on a grid pattern of narrow streets. The population of Valletta reached its peak in 1911 with 23,006 residents and then declined rapidly following the heavy bombing of the Harbour during the wars down to 5784 in 2011, therefore a 75\% decline over 100 years. Valletta in the meantime became the seat of Government, the main commercial and retail centre for the island, attracting a considerable number of daily trips. In 1998 the Household Travel Survey estimated that $11 \%$ of all trips made in the island started or ended in Valletta. This is relatively high when compared to other major centres such as Sliema (6\%). It was estimated that Valletta and its suburb Floriana attract in the region of 55,000 workers over a 24-h cycle in 2004 (Cabinet Committee for National Projects, 2005).

The V-licence was implemented by the Police in the 1960s following the realization that Valletta had limited space for traffic circulation. The V-licence was a fixed annual fee paid for access and parking in the City. By 2007 the fee had been raised to $€ 46$, paid with the annual circulation tax. By 2004, 32,128 car owners had the V-licence, excluding some 5000 residents that were exempt and with only 3000 legal parking spaces available in the City, it was evident that most car owners paid the V-licence for occasional use. Despite this its contribution to the Government Consolidated Fund was considerable (€1.4 m in 2004) (Attard and Ison, 2010).

There were concerns about the merit of the $\mathrm{V}$-licence in banning cars during the day when the demand was high, but also at night when demand was low. Cultural venues suffered a lack of business in the evening since many were disqualified from accessing the city a priori. The night also provided insights into the actual number of resident vehicles in the city. It was evident that many registered their address in Valletta to avoid paying the V-licence.

Whilst the V-licence in itself was a fee for access and parking, the on-street parking was provided on a 'first come first serve basis' which also meant that commuters occupied parking spaces for $8 \mathrm{~h}$, affecting negatively the use of spaces by visitors and residents. A survey carried out prior to the introduction of the CVA showed the parking situation in Valletta. Despite some 2985 on-street parking spaces, half of which were used by the small resident population, over 5000 vehicles were registered as parked in Valletta by 11:00 am. Fig. 3 shows the patterns of use indicating the city's available spaces filled by commuters by $8: 00 \mathrm{am}$. The impact of so many parked vehicles reflected on the use of public spaces within the City. The few market squares, designed originally as open spaces were congested with parked vehicles, whilst parking was also allowed on pavements and pedestrian walkways. Access to homes and walking had become a challenge for both residents and visitors (Cabinet Committee for National Projects, 2005).

Following the introduction of the Controlled Vehicular Access system and the extension of the pedestrian area, the number of parking spaces in the city was reduced by over $11 \%$. Over $18 \%$ was allocated to resident parking during the night, and just over $5 \%$ was allocated permanently to residents (Malta House of Representatives, 2007). Parking surveys were carried out pre and post implementation of the Valletta projects. These revealed that on a typical weekday 9.5\% less vehicles parked in Valletta. The amount of vehicles parked at peak time (10:00-11:00) reduced by $26.7 \%$ and the average parking duration went down from 3.9 to $3.5 \mathrm{~h}$ (Informa Consultants, 2006, 2007).

The Controlled Vehicular Access system, as described in Section 4 operates on a pay per use model. It allows access to the city to all and charges according to the time spent in the charging zone. This is done via camera technology that captures and records entry and exit times of each vehicle.

As identified by Attard and Ison (2010), the Controlled Vehicular Access system has a number of advantages, amongst which are that it:

- discriminates against commuters and encourages shorter visits for shopping and entertainment (Delia, 2007);

- increases parking turnover in the area closest to the city's commercial centre;

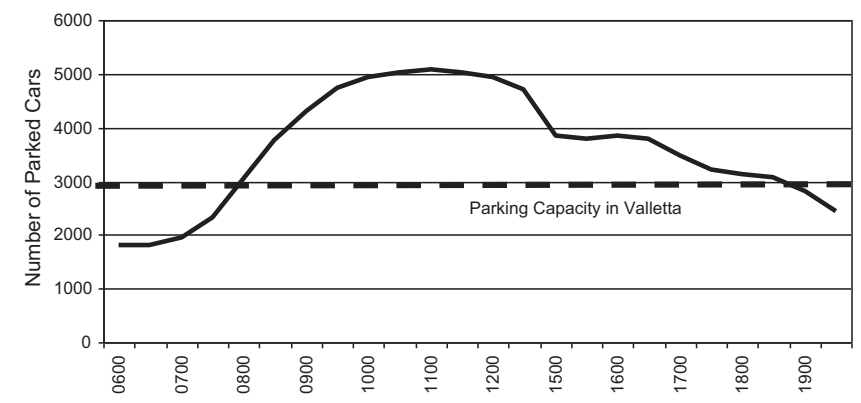

Fig. 3. Parking capacity and usage in Valletta on a typical weekday prior to the introduction of the road user charge (Cabinet Committee for National Projects, 2005). 


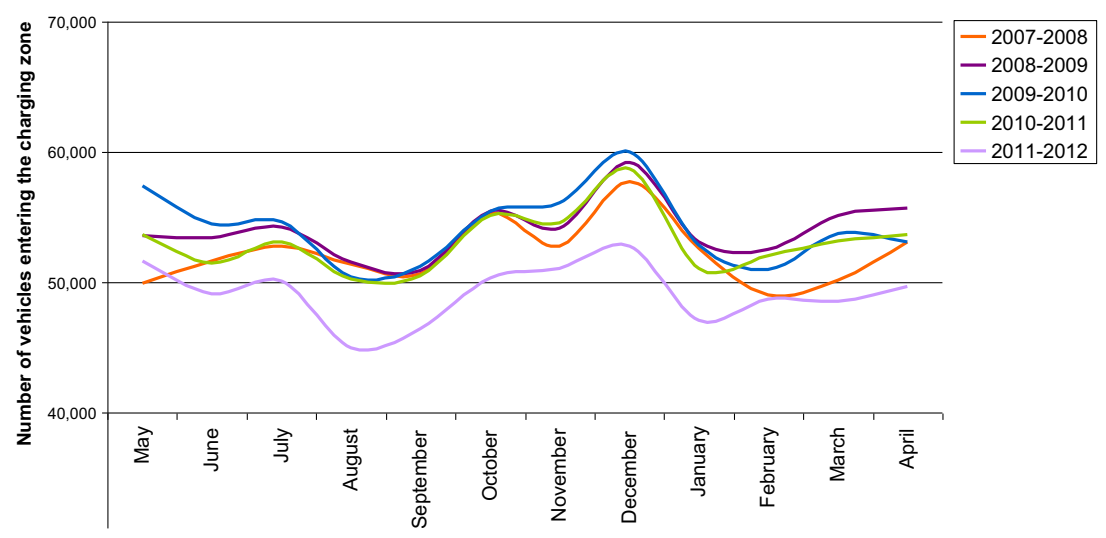

Fig. 4. Number of vehicles entering the charging zone between May 2007 and May 2012 (CVA Technology Ltd, 2013).

- allows for changes to the system to be activated easily through technology (Mamo and Dalli, 2007);

- allows for a fairer system of assigning residency (Delia, 2007);

- allows customer interaction for viewing and paying the charge (Mamo and Dalli, 2007); and

- allows and encourages visitors to the city during low demand.

Fig. 4 shows the number of vehicles that have entered the charging zone since its inception in May 2007 up until May 2012. There is evidence of increased traffic particularly after the first year of operation with a $3.4 \%$ increase in the number of vehicles entering the charging zone. This is probably due to an attenuation of the effects of the charge after one year. This attenuation however is less pronounced in the autumn and winter months with more variations over the spring and summer months. A negligible increase $(0.3 \%)$ was witnessed in the third year of operation and by 2010 the number of vehicles entering the zone declined by $2 \%$. The low number of vehicles recorded in 2011 (a decline of $7.4 \%$ over 2010) was due to infrastructure projects in the City which reduced the access into the city and limited circulation and parking. The effects of such infrastructure development require investigation once the major projects in Valletta are completed.

In order to compare the V-licence parking fee to the CVA road user charge, data from the National Household Travel Survey was used so as to show differences in modal split and car use. Fig. 5 shows the modal share of all trips recorded in the surveys ending in Valletta in 1998 and 2010. The 1998 dataset represents the modal split under the V-licence regime whilst the 2010 dataset shows modified patterns of modal split, three years after the implementation of the road user charge. The $10 \%$ shift from private to public

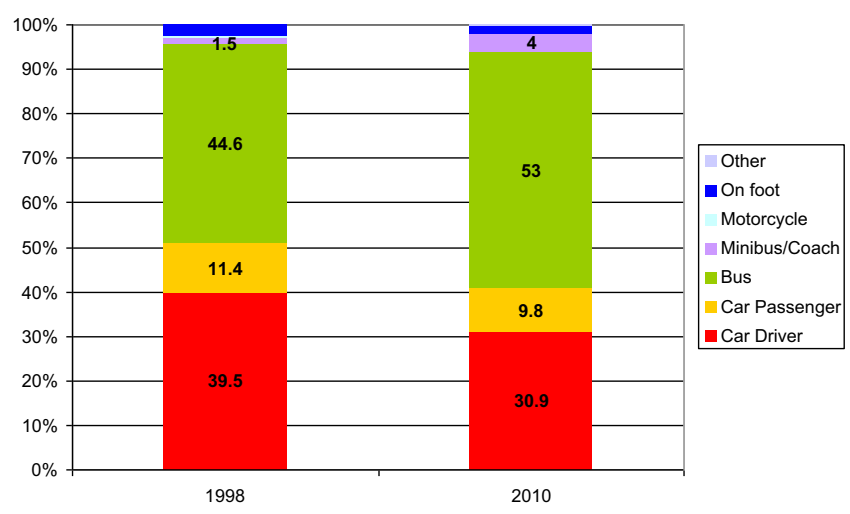

Fig. 5. The modal shift for trips ending in Valletta before and after road user charging (Transport Malta, 2010). transport modes is evident and very positive. This result is significant because it happened during a time when the islands were experiencing the most rapid growth in car ownership. Even though it is hard at this point to attribute this shift completely to the change from a parking fee to a road user charge, the Valletta projects, of which the CVA is a major component, were the most influential measures to affect travel behaviour.

It is also important to note that this modal shift did not occur all round the island. In fact Valletta was the only city that experienced this change, which is in stark contrast to the national trends of increasing car usage, starting from $54.7 \%$ of trips carried out by car in 1989 , rising to $70.2 \%$ of all trips in 1998 and further increasing to $74.6 \%$ in 2010. The share of public transport fell from $24.3 \%$ in 1989 to $11.3 \%$ in 2010 and walking down from $11.6 \%$ in 1989 to $7.6 \%$ in 2010 (Transport Malta, 2010).

In addition to this change in behaviour it is important to add that whilst $37.6 \%$ claimed to have a car available for their trip to Valletta in 1998 , this increased to $47.8 \%$ in 2010 . There is thus a realization, possibly brought about by the CVA and the car restraint policies adopted in Valletta between the period 2006 and 2007, that modal shift is inevitable.

\section{Conclusions}

The findings presented in this study indicate a modal shift in the city of Valletta. In the period under review, major changes in transport policy have occurred, including the introduction of road user charging. Other factors affecting this shift might have been driven by land use changes, which were not significant during the period in question, infrastructure capacity which has been an issue in Valletta since the 1960s and the overall quality of public transport provision to the City which has been always centred around the main hub of Valletta with direct services to all towns and villages within the island.

Despite these possible factors, positive and measurable impacts have been identified following the introduction of a road user charging scheme in Valletta in 2007. At the time of writing, pressure is being placed on the recently elected government to provide parking and resolve the issues in which Local Councils are seeking to reserve parking for residents, trade unions are lobbying for parking charges and employee unions are demanding protection of free on-street parking. Issues of charging, equity and fairness are mostly being presented and discussed in the media.

The road user charge implemented in Valletta can be perceived as a fair system that allows equal access to infrastructure which is in high demand. It removed the restrictions dictated by the fixed annual charge and increased the turnover of spaces within the charging zone. The reduction in the volume of traffic within the 
city walls is also a positive sign affecting the natural and built environment and improving the quality of life of residents and workers. Further monitoring of the traffic levels will be required once the infrastructural and regeneration works have been undertaken over the coming years.

In addition, a change in travel behaviour towards the city was observed during the period under study. A modal shift is evident with more trips being carried out by bus to the city, even when a private car is available. Stronger parking policies, particularly those involving pricing would add more value to the limited parking capacity of the City. Parking fees, integrated with the road user charge would ensure the maximum return on parking facilities. An access and circulation fee could easily be separated from a parking charge which reflects not only the time spent in the zone but also the location of the parking space with respect to centrality and proximity to the retail centre. Measures envisaged to protect residents (and the extensive exemptions) also need to be revised as the City regains popularity, and regeneration sees an increase in the resident population over time. Over-protection of residential parking might not be a sustainable policy in the long term, however this is a subject for further research.

The findings of this study have shown that it is viable and possible to introduce road user charging as a more effective and efficient pricing mechanism within an urban environment. The considerations for such schemes however must follow well-known critical issues that affect their implementation. These generally relate to the purpose and objectives of the scheme, the design criteria and above all, the political champion. Thus as cities change, as is the case with Valletta with new infrastructure projects eventually affecting its land use and transport system with a change in Government and political direction, the challenges lie with monitoring the system performance, maintaining control on internal processes so as to ensure efficiency, and updating of the scheme to ensure effectiveness.

\section{References}

Albert, G., Mahalel, D., 2006. Congestion tolls and parking fees: a comparison of the potential effect on travel behaviour. Transp. Policy 13, 496-502.

Alternattiva Demokratika, 2013. Manifest Elettorali 2013. Available at http:/ www.alternattiva.org/mothership/wp-content/uploads/2011/08/AD_Manifesto 2013_A4.pdf (accessed 20.02.13).

Attard, M., 2006. Coping with Change. The Problems of Adopting Sustainable Transport Policies in the Small Island State of Malta. (Ph.D. Thesis)University College London, London, UK.

Attard, M., Ison, S.G., 2010. The implementation of road user charging and the lessons learnt: the case of Valletta, Malta. J. Transp. Geogr. 18, 14-22.

Bonsall, P., Young, W., 2010. Is there a case for replacing parking charges by road user charges? Transp. Policy 17, 323-334.

Brown, G., McKellar, R., Landsell, H., 2004. A regional parking strategy for Perth. In: World Parking Symposium IV.

Burgess, R., 1984. In the Field. An Introduction to Field Research. Routledge, London.
Button, K., Vega, H., 2008. Road user charging. In: Ison, S., Rye, T. (Eds.), The Implementation and Effectiveness of Transport Demand Management Measures: An International Perspective. Ashgate, London.

Cabinet Committee for National Projects, 2005. Valletta and Floriana: A Strategy to Improve Access. Government of Malta.

CVA Technology Ltd, 2013. Personal Communication. Marsa, Malta, 7th March 2013.

de Palma, A., Lindsey, R., 2011. Traffic congestion pricing methodologies and technologies. Transp. Res. C 19, 1377-1399.

Delia, E., 2007. Personal Communication. Ministry for Information, Technology and Investment, Cabinet Committee for National Projects, Valletta, Malta, 8th November 2007.

European Commission, 2012. EU Transport in Figures, Statistical Pocketbook for 2012. Publications of the European Union, Luxembourg.

Informa Consultants, October 2006. Parking Survey for Valletta, Malta.

Informa Consultants, November 2007. Parking Survey for Valletta, Malta.

Ison, S.G., 2004. Road User Charging: Issues and Policy. Ashgate Publishing, London. Ison, S.G., Rye, T., 2005. Implementing road user charging: the lessons learned from Hong Kong, Cambridge and Central London. Transp. Rev. 25, 451-465.

Litman, T., 2006. Parking Management Best Practice. APA Planners Press, USA.

Malta House of Representatives, 2007. Parliamentary Question PQ25777 Parkegg fil-Belt. Available at http://www.pq.gov.mt/PQWeb.nsf/10491c99ee75af51c1 2568730034d5ee/c1256e7b003e1c2dc12572d6005010c2?OpenDocument (accessed 04.06.14).

Mamo, A., Dalli, A., 2007. Personal Communication. CVA Technology Company Ltd. Marsa, Malta, 29th June 2007.

Meyer, M.D., 1999. Demand management as an element of transportation policy: using carrots and sticks to influence travel behaviour. Transp. Res. A 33. 575-599.

Ministry for Transport, Road Pricing: The Economic and Technical Possibilities [The Smeed Report]. HMSO, London.

National Statistics Office, 2011. Malta in Figures. National Statistics Office, Malta.

Nationalist Party, 2012. Another Quality Leap: Work Health Education. Electoral Programme of the Nationalist Party 2013. Information Office of the Nationalist Party, Malta. Available at http://mychoice.pn/docs/ElectoralProgrEN.pdf (accessed 08.02.13).

Newbery, D., 1990. Pricing and congestion: economic principles relevant to pricing roads. Oxf. Rev. Econ. Policy 6, 22-38.

Partit Laburista, 2013. Malta Taghna Lkoll. Manifest Elettorali 2013. Partit Laburista, Malta. Available at http://election.josephmuscat.com/manifest.pdf (accessed 20.02.13).

PRoGR€SS, Pricing Road use for Greater Responsibility, Efficiency and Sustainability in cities. Available at http://www.progress.project.org (accessed 27.02.13).

Shoup, D., 2005. The High Cost of Free Parking. APA Planners Press, USA.

Shoup, D., 2006. Cruising for parking. Transp. Policy 13, 479-486.

Times of Malta, 2013a. Sliema business community objects to parking scheme. Available at http://www.timesofmalta.com/articles/view/20130219/local/sliemabusiness-community-objects-to-parking-scheme.458331 (accessed 20.2.13).

Times of Malta, 2013b. Updated: Sliema council wants to be heard on parking scheme. Available at http://www.timesofmalta.com/articles/view/20130727/ local/sliema-council-wants-to-be-heard-on-parking-scheme.479714 (accessed 29.07.13)

TM (Transport Malta), 2010. National Household Travel Survey 2010. Report of Survey. Available at http://www.transport.gov.mt/admin/uploads/medialibrary/files/NHTS 2010\%20Report.pdf_20120502091559.pdf (accessed 20.02.13).

TM (Transport Malta), 2012. Transport Malta publishes concession tenders for the operation of 34 public car park sites currently administered by licensed car park attendants. Available at http://www.transport.gov.mt/news/press-releasetransport-malta-issues-car-parks-concession-tender (accessed 20.02.13).

Verhoef, E., Nijkamp, P., Rietveld, P., 1995. The economics of regulatory parking policies: the (im)possibilities of parking policies in traffic regulation. Transp. Res. A 29, 141-156.

Young, W., 2008. A view of parking policy in an Australian city. In: Ison, S., Rye, T. (Eds.), The Implementation and Effectiveness of Transport Demand Management Measures: An International Perspective. Ashgate, London. 